\title{
LONG-TERM PROGNOSIS OF SOFT-TISSUE INJURIES OF THE NECK
}

\author{
M. F. GARGAN, G. C. BANNISTER
}

From the University of Bristol

\begin{abstract}
We reviewed 43 patients who had sustained soft-tissue injuries of the neck after a mean 10.8 years. Of these, only $12 \%$ had recovered completely. Residual symptoms were intrusive in $28 \%$ and severe in $12 \%$. Pain in the neck and lower back was the commonest complaint and older patients had a worse prognosis. After two years, symptoms did not alter with further passage of time.
\end{abstract}

It is difficult to give a confident long-term prognosis for patients who have suffered soft-tissue injuries of the neck following a rear-end collision. Studies of the condition have been handicapped by incomplete follow-up ( $\mathrm{McNab}$ 1964; Hohl 1974) and by selective patient sampling (Gotten 1956; Schutt and Dohan 1968). There appeared to be a need for a long-term sequential review of patients with this condition to establish its prognosis.

\section{PATIENTS AND METHODS}

Between September 1977 and May 1980, 61 consecutive patients with soft-tissue injuries of the neck were seen at the Bristol Royal Infirmary, and the results were assessed some two years later (Norris and Watt 1983). In the present study, the same patients were reviewed again, eight to 12 years after injury. They were examined clinically and were questioned about the mechanism and circumstances of the accident, residual symptoms, rate of recovery, and results of any litigation.

\section{RESULTS}

Of the 61 patients initially studied, five had died and 13 could not be traced. The remaining 43 were 21 males and 22 females. The age of the males averaged 53 years (range 29 to 68 ) and females 44 years (range 29 to 62). The mean follow-up period was 10.3 years (range 8 to 12 ).

M. F. Gargan, FRCS, Registrar in Accident and Emergency Surgery John Radcliffe Hospital, Headington, Oxford OX3 9DU, England.

G. C. Bannister, MChOrth, FRCS Ed(Orth), FRCS, Consultant and Senior Lecturer

Department of Orthopaedic Surgery, Southmead General Hospital, Westbury-on-Trym, Bristol BS10 SNB, England.

Correspondence should be sent to Mr G. C. Bannister.

(C) 1990 British Editorial Society of Bone and Joint Surgery $0301-620 X / 90 / 5183 \$ 2.00$

J Bone Joint Surg [Br] 1990; 72-B:901-3.
Mechanism of injury. In our group of patients, $88 \%$ had been involved in rear-end collisions and $48 \%$ had been wearing seat-belts.

\begin{tabular}{lr}
$\begin{array}{l}\text { Table I. Residual symptoms at follow-up } \\
\text { (per cent) }\end{array}$ \\
\hline Neck pain & 74 \\
Paraesthesia & 45 \\
Lower back pain & 42 \\
Headache & 33 \\
Dizziness & 19 \\
Auditory symptoms & 14 \\
Dysphagia & 2 \\
Visual symptoms & 2 \\
\hline
\end{tabular}

Symptoms. Neck pain (Table I) was the most common symptom, followed by paraesthesia. Thoracic or lumbar backache affected $42 \%$ of patients, a little under half of whom considered it more troublesome than their neck pain. A further $9 \%$ of patients suffered from low back pain that predated their accident. Auditory symptoms comprised tinnitus and deafness in equal proportion. One patient with visual symptoms had multiple sclerosis diagnosed five years after her accident, and another with dysphagia was noted to have a benign oesophageal stricture. Neither, therefore, were attributed to the accident.

Severity of symptoms. Patients were subdivided into four groups on the basis of their symptoms. Group A (12\%) were free of any discomfort and considered that they had made a complete recovery from their accident. Group B $(48 \%)$ were left with mild symptoms which did not 
interfere with their work or leisure activities. Group C $(28 \%)$ complained of intrusive symptoms which handicapped work and leisure and caused them to seek relief by frequent intermittent use of analgesia, orthoses or physiotherapy. Group D (12\%) suffered from severe problems, had lost their jobs, relied continually on orthoses or analgesics, and had undergone repeated medical consultations.

The mean age of patients in group A was 41 years; this was significantly lower than those in group $D$, who averaged 56 years $(\mathrm{p}<0.05)$.

\begin{tabular}{|c|c|}
\hline Group* & Months \\
\hline A & 0.6 \\
\hline B & 0.5 \\
\hline C & 1.74 \\
\hline D & 3.15 \\
\hline
\end{tabular}

Rate of recovery. Table II shows the time taken to recover from the acute episode. Group B patients had improved significantly more quickly than those in group $C$ $(p<0.05)$. Group D had reached their chronic state after about three months.

Table III. Mean ranges of movement of the neck at follow-up in degrees

\begin{tabular}{llll}
\hline & Group & & \\
\cline { 2 - 4 } & A & B + C & D \\
\hline Flexion/extension & 125 & 108 & 93 \\
Rotation & 75 & 58 & 52 \\
Lateral flexion & 38 & 27 & 26 \\
\hline
\end{tabular}

Litigation. Compensation had been claimed by $56 \%$ of patients. The average award was $£ 1,436$ (sterling), and the average time to settlement was 19 months. The amount of compensation and the time required to reach settlement correlated with the severity of symptoms at long-term follow-up. Claims of over $£ 1,000$ were concluded after a mean of 27 months, whereas those for less were settled after 15 months $(\mathrm{p}<0.05)$. Patients in group $D$ averaged 28 months before compensation, compared with 15 months in groups $B$ and $C$.
Neck stiffness. The range of neck movement was significantly greater in asymptomatic patients but did not vary between groups B, C and D (Table III).

\section{DISCUSSION}

Of patients attending hospital after road traffic accidents $30 \%$ complain of neck pain, and delayed symptoms occur in a further $35 \%$ (Deans et al 1987). Rear-end collision with consequent hyperextension of the neck is consistently the cause of injury (McNab 1964; Norris and Watt 1983; Deans et al 1987), and seat-belts alone afford no protection.

Our series comprised victims of road traffic accidents; others have consisted of prospective litigants (Gotten 1956), claimants from insurance companies (Schutt and Dohan 1968), or patients attending office practices on the West Coast of North America (Hohl 1974). Despite this variety of samples, there is a general uniformity about the results reported, if not in their interpretation.

Symptoms. Table IV shows that the symptoms are reported with comparable frequency by the several authors. There is little difference between the assessments made after one year and eight years, and it would seem that most patients have reached their final state within two years of injury (Hohl 1974).

Table IV. Percentage with symptoms at follow-up, from four series

\begin{tabular}{lccll}
\hline & $\begin{array}{l}\text { Schutt and } \\
\text { Dohan 1968 }\end{array}$ & $\begin{array}{l}\text { Hohl } \\
1974\end{array}$ & $\begin{array}{l}\text { Norris and } \\
\text { Watt 1983 }\end{array}$ & $\begin{array}{l}\text { Gargan and } \\
\text { Bannister 1990 }\end{array}$ \\
\hline Neck pain & 100 & 98 & 64 & 74 \\
Headache & 70 & 72 & 42 & 33 \\
Paraesthesia & 7 & 36 & 37 & 45 \\
Dysphagia & 0 & 0 & 0 & 0 \\
Visual & 1 & - & 13 & 2 \\
Auditory & 3 & - & 13 & 14 \\
Vertigo & 8 & - & - & 19 \\
Backache & - & 35 & - & 42 \\
$\begin{array}{l}\text { Minimum } \\
\text { follow-up (yr) }\end{array}$ & 0.5 & 1 & 5 & 8 \\
\hline
\end{tabular}

Table V. Percentage with symptoms at follow-up from three series

\begin{tabular}{lllc}
\hline & \multicolumn{2}{l}{ None or mild } & \multicolumn{2}{l}{ Moderate } & Severe \\
\hline Gotten (1956) & 54 & 34 & 12 \\
Hohl (1975) & 57 & 37 & 6 \\
Gargan and & 60 & 28 & 12 \\
Bannister 1990 & & & \\
\hline
\end{tabular}


Many studies record the symptoms but do not define their severity. McNab (1964) observed that in the majority of cases the symptoms constitute a nuisance rather than a disability. Those authors who have assessed severity concur that between $6 \%$ and $12 \%$ of patients will be severely affected (Table V).

Thus far, it has not been possible to reliably predict the long-term outcome, and most previous authors were unable to reconcile symptoms with physical signs. Norris observed that patients with objective neurological signs and restriction of neck movement were more likely to experience continuing symptoms, but was not able to relate this to their severity.

The imprecise correlation of symptoms with signs and the frequency with which the victims of such injuries pursue legal action suggests the possibility that complaints might be overstated to enhance financial settlement. Numerous authors (Gay and Abbott 1953; Gotten 1956; Farbman 1973; Hohl 1974) have pointed to the association of continuing symptoms with protracted legal proceedings. However, larger settlements are awarded to more severely affected patients, and these take longer to conclude. Schutt and Dohan (1968) positively identified subjective symptoms in less than $2 \%$ of their cases, and
McNab (1964) and Norris and Watt (1983) recorded that symptoms remained unchanged in those whose claims had been settled. The fact that symptoms do not resolve even after a mean 10 years supports the conclusion of these authors.

No benefits in any form have been received or will be received from a commercial party related directly or indirectly to the subject of this article.

\section{REFERENCES}

Deans GT, Magalliard JN, Kerr M, Rutherford WH. Neck sprain - a major cause of disability following car accidents. Injury 1987; 18:10-2.

Farbman AA. Neck strain: associated factors. JAMA 1973; 223: 1010-5.

Gay JR, Abbott KH. Common whiplash injuries of the neck. JAMA 1953; 152:1698-1704.

Gotten N. Survey of one hundred cases of whiplash injury after settlement of litigation. JAMA 1956; 162:865-7.

Hohl M. Soft-tissue injuries of the neck in automobile accidents. $J$ Bone Joint Surg [Am] 1974; 56-A:1675-82.

Hohl M. Soft tissue injuries of the neck. Clin Orthop 1975; 109:42-9.

McNab I. Acceleration injuries of the cervical spine. J Bone Joint Surg [Am] 1964; 46-A : 1797-9.

Norris SH, Watt I. The prognosis of neck injuries resulting from rearend vehicle collisions. J Bone Joint Surg [Br] 1983; 65-B :608-11.

Schutt CH, Dohan FC. Neck injury to women in auto accidents. A metropolitan plague. JAMA 1968; $206: 2689-92$. 